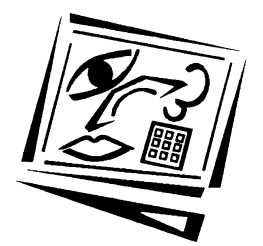

\title{
Course design and student responses to an online PBL course in 3D modelling for mining engineers
}

\author{
Iain McAlpine and Phillip Stothard \\ The University of New South Wales
}

\begin{abstract}
To enhance a course in 3D Virtual Reality (3D VR) modelling for mining engineers, and to create the potential for off campus students to fully engage with the course, a problem based learning (PBL) approach was applied to the course design and all materials and learning activities were provided online. This paper outlines some of the theoretical background to online learning and PBL and its application to computer based courseware design and development. The application of this approach to the 3D VR modelling course is described. Evaluation data on student perceptions of the learning processes associated with PBL are included.
\end{abstract}

\section{Introduction}

Most of the literature on online learning that deals with situations in which the whole course is online, is concerned with off campus users. Increasingly however, online learning environments are used with on campus students in a blended learning approach (Bonk, Kim \& Zeng, 2005; Bunker \& Vardi, 2001) or, possibly, a mix of on campus and off campus students doing the same course. The introduction of online learning environments to on campus courses may be to enable approaches that are more student centred (Bunker \& Vardi, 2001), to encourage students to be active self directed learners (Tolhurst, 2002), to develop capabilities in problem solving (Reeves \& Okey, 1996), and to attain higher order learning outcomes (ACDE, 2001). Introduction of online technologies may also be associated with changes in teaching methods designed to enhance the capabilities for student use to build graduate attributes, such as communication skills, problem solving, teamwork, and negotiation skills.

Do students want to be self directed active learners diligently acquiring a range of generic and discipline specific skills that will prepare them for their future careers? In many cases it appears they don't, and would rather 
be told what they need to know than be asked to directly pursue a deeper understanding for themselves (Collis \& Moonen, 2001; Tolhurst, 2002). An online learning environment may provide a perfect environment for exploration of the topic, but students may still prefer a classroom (Jones \& Richardson, 2002). Online learning has been seen to be supply driven by universities rather than demand driven by students (Senate Committee Report, cited in Jones \& Richardson, 2002). If students are going to be self directed learners who can make the best use of online learning environments, on or off campus, they may need to be guided and supported to develop this capability (Collis \& Moonen, 2001).

This article considers some of the issues associated with using an online learning environment with on campus students in a blended learning approach. The course, on 3D VR Modelling for Mining Engineers at the University of New South Wales, is considered from the perspectives of educational design, development of the online learning environment, and student evaluation. Research literature on educational design and applications of online learning approaches is considered to identify the key issues relating to online learning environment design and implementation. Student feedback raises some issues relating to the effectiveness of the course and the value of using an online environment with on campus students. This feedback will be discussed in relation to the course design, with some recommendations made for design and use of online environments on campus.

\section{Educational design for online courses}

The design approach used for VR Modelling for Mining Engineers can be considered in the broader context of educational research and development relating to online technologies. Aims for course development included enhancing student learning using a blended learning approach, and developing a design for the online learning environment that would make the course accessible to off campus students if a decision was made to offer the course externally in future. At the time of the development there were no off campus students so the development was intended as a trial for on campus use. The educational design had to be robust and yet meet the needs of very different groups of students. It needed to be a flexible approach that could provide access to the entire course online, while being of value to on campus learning and teaching approaches.

\section{Student centred learning}

While there is a wide range of literature on the topic of educational design for online learning, two major themes emerged as being of particular relevance to this project. Both themes are concerned with educational 
processes that apply whether online learning processes are used or not. The first theme is that learning and teaching processes should be student centred, and that one way to bring about a change of emphasis in teaching, from the teacher directed approach to a facilitated approach, is to change the medium of instruction (Kearsley, 2000). Reasons for making a change to online approaches for students who are on campus may vary. One reason, however, is that teachers may be discontented with the results of student learning, and are looking for ways to enhance learning outcomes and to help students to be more self directed. A course in introductory computing, for example, was changed from a large lecture format to providing students with a website and resources to research the course topics to prepare for small class meetings. Class contact was reduced. The class discussions however were more focused as the students came prepared to discuss their ideas (Tolhurst, 2002). In another case, teachers found classroom discussions to be insufficiently thoughtful and used asynchronous discussions as an alternative. While this required teachers to learn new skills as online facilitators, online discussions were found to foster a deeper and more reflective discussion than the equivalent classroom tutorial (Bunker \& Vardi, 2001; Newman, Johnson, Webb \& Cochrane, 1997).

While these approaches appear to have been effective, they are not necessarily problem free. The issue of learning new skills and facilitation becomes important if a change towards this approach is contemplated. The use of online discussions, for example, may attract little student activity, unless there is a clear task to accomplish, that requires the online discussion (Bunker \& Vardi, 2001; Salmon, 2002). Online discussions may be an unfamiliar mode for students, and they may need some focused encouragement to engage with the teacher and each other in this way.

\section{Learning activities}

The second major theme that emerged from the literature is the importance of providing an activity focus for the students. Course 'content' in the form of information in various formats may not be motivating unless the student needs to do something with it. A key design approach is to make the learning activity, rather than the course materials, the focus for the course design (Collis \& Moonen, 2001; Oliver \& Herrington, 2001). By asking the students to carry out a task that requires them to use the information included in the course, such as a problem or case based approach, a design task, or to design an experiment and report on the outcome, students need to apply the course material which should foster a more active engagement (Oliver \& Herrington, 2001). In an online environment, students need communication channels such as online discussion, as well as access to the 
relevant information, to be able to engage with other students and the tutor so that the learning activity can be carried out effectively.

The activity focus for educational design is seen to be a valuable way to develop a deeper understanding of the course topic (Biggs, 1999a). Additionally it is seen to be of value in developing a broader range of student capabilities, such as communication, negotiation, problem solving and teamwork skills (Bowden, Hart, King, Trigwell \& Watts, 2000). The Manual for the Accreditation of Professional Engineering Courses lists:

- ability to communicate effectively, not only with engineers but also with the community at large

- ability to undertake problem identification, formulation and solution

- ability to function effectively as an individual and in multidisciplinary and multicultural teams with the capacity to be a leader or manager is well as an effective team member

among the generic attributes of an engineering graduate (IEAust, 1999). An educational design approach focused on activities can help to develop these graduate attributes by requiring and supporting processes of communication, teamwork and problem solving, during the course.

The two major themes from the literature research relating to a student centred approach, using a design based on learning activities, were used as a basis for the course redesign. The course is designed for mining engineers, however emerging difficulties in occupational health and safety legislation and logistics make it difficult for the students to spend much time in a working mine. This made it desirable to bring the mine to the students instead and it was intended that students from other mining schools could ultimately use the course as 'off campus students'. To meet all of the emerging requirements a problem based learning (PBL) approach was chosen to provide an appropriate learning activity basis for the course design. This approach is designed to encourage the development of student skills and capabilities. A meta-analysis of research studies on the effectiveness of PBL revealed that this approach had a strong positive effect on skill development and led to longer term retention of the knowledge developed while learning (Dochy, Segers, Van den Bossche \& Gijbels, 2003). Skill development includes the skills associated with the course topic, and skills in communication, teamwork and problem solving that are among those valued by professional bodies and employers (Kanet, 2003; Keppell, 2005).

\section{Problem based learning}

The PBL approach is based on a need to make education challenging and interesting for the student by structuring the learning process around 
learning activities based on complex, real world problems (Koschmann, Kelson, Feltovich \& Barrows, 1996; Savin-Baden, 2000). The PBL method applies constructivist principles by using problems or issues for which there is no single answer or resolution. The learning tasks are meaningful to the student, because the resolution to the problem must be constructed by the students themselves, based on their own experiences; both prior experience and those related to the learning activities associated with a problem task (Biggs, 1999b). To ensure that there is no one 'right' answer problems should be ill-structured, so that students have a high degree of flexibility in the way that they resolve the problem (Jonassen \& Reeves, 1996). Active learning by problem solving is a key aspect of a constructivist learning environment (Reeves \& Okey, 1996).

The PBL approach arose out of the need for learning and teaching to be relevant to the students' interests and future goals (Savin-Baden, 2000). The basic scientific knowledge required by medical students for example, may be learned in relation to the clinical context in which the knowledge is applied, rather than in an abstract, pure science format (Koschmann et al, 1996). The approach is designed to apply the key principles of cognition to the design of the learning activities and processes. These include providing scope for the learner to apply prior knowledge and experience to the task, encouraging and enabling the learner to actively extend their experience and knowledge base, creating a realistic context for learning so that the learner can apply the new knowledge in the future professional context, and developing the ability to articulate knowledge and skills to new situations (Koschmann et al, 1996; Savin-Baden, 2000). This has been seen as a way of validating theoretical learning through practice, and for using evidence to generate theory from enquiries made in practice (Anthonysamy, 2005). The application of these principles has a metacognitive dimension, enabling learners to become more skilled at managing their own learning (Biggs, 1999a).

The key to effective PBL is the actual problem scenario, including any guidelines or supports that provide the trigger for learning and shape the directions the process may take. A problem that is too prescriptive will limit the scope and flexibility of student learning, while one that is too open may lead to students taking inappropriate directions and/or feeling frustrated by not having sufficient criteria or guidelines to conceptualise what a successful outcome may be. There can be confusion between the idea of learning that includes problem solving, and PBL in which the whole learning process revolves around high level problems (Savin-Baden, 2000). The following principles for problem scenarios provide a useful guide to suitable problems: 
- The contents of a problem should adapt well to students' prior knowledge.

- A problem should contain several cues that stimulate learners to elaborate.

- Preferably, present a problem in the context that is relevant to the future profession.

- Present relevant basic concepts in the context of a problem to encourage integration of knowledge.

- A problem should stimulate self directed learning by encouraging students to generate learning issues and conduct literature searches.

- A problem should enhance students' interest in the subject matter, by sustaining discussion about possible solutions and facilitating students to explore alternatives.

- A problem should match one or more of the course learning outcomes. (After Dolmans, Snellen-Balendong, Wolfhagen \& van der Vleuten, 1997).

The value of the PBL approach may be enabled or enhanced by appropriate use of online technologies. Tasks such as organising the syllabus and course materials, organising groups through online discussions, and organising projects and reports can all be accomplished online in ways that promote the success of PBL courses (Watson, 2002). The addition of multimedia resources to an online support framework can further enhance the process. Using multimedia to present complex scenarios in a realistic manner has been found to successfully motivate students to investigate PBL scenarios (Challis, Holt \& Rice, 2005; Keppell, 2005). Multimedia presentation or scenarios is one way of adding authenticity to the PBL process. An essential feature of PBL is that the scenario represents a 'real world' problem, which contributes to student motivation to learn using this approach (Keppell, 2005; McAlpine \& Clements, 2001; Watson, 2002).

The perception of authenticity encourages the students to 'believe' in scenarios that are realistic in the way they represent a professional environment that is not truly real (Herrington, Oliver, \& Reeves, 2003). Some examples of using multimedia for scenario presentations are trigger videos on a range of topics developed to support specific courses and to be reusable learning objects (Keppell, 2005), video case studies for a PBL course in pasture management (McAlpine \& Clements, 2001), and a comprehensive learning environment used by journalism students to experience the demands of working within a tight time frame with other industry pressures added (Challis et al., 2005). Multimedia resources can also be used to provide simulated tools to enable students to work with and test their development, while working out their solution to a problem (Anthonysamy, 2005). The use of online learning environments can enable students to work in a self directed way to realise the full value and benefits of the PBL approach. 
As learning in the PBL framework is initiated by considering a problem scenario, developing a scenario and guidelines that are based on the above principles using multimedia support for scenario presentation will provide sufficient depth and scope for a learning activity that may take several weeks and be a significant part of a course. PBL combines student centred learning with a clear task oriented learning activity - the two key themes identified above as critical aspects of an online learning environment. This was the basis for the approach used to design the course learning activities. The following section describes the application of PBL and the development of online courseware in an open learning environment format (Hannafin, Land \& Oliver, 1999) to enable the students to accomplish the problem task.

\section{Case study: Mine simulation and modelling}

Mine 4800: Mine Simulation and Modelling is a fourth year Mining Engineering elective. The course is offered with supporting courseware using the WebCT facility at UNSW. The aim of the course is to introduce students to various mine simulation and modelling tools and provide them with the knowledge to address mine safety, production and engineering problems at mine sites. The course material is accessible online and is intended to be a supplement to informal seminars and tutorials in a blended learning environment. Formal lectures are not given to the students. The course was run in its current form with 16 students in 2002 and 9 students in 2003. Participants were fourth year Mining Engineering students, aged 20-25 years. Low student numbers are a result of the low numbers enrolled in mining engineering in general. In 2003 in Mining Engineering there were a total of 28 students and in 2003 there were 23 students. The numbers for Mine 4800 were capped to stop the course starving other electives of students. Due to staff changes the course was not offered in 2004 or 2005. This meant that the planned potential for offering the course in off campus mode has not been realised.

\section{Design}

An example of the layout of the course materials is shown in Figure 1. The information contained in the WebCT section of the course is designed around the design principles for an open learning environment. The design incorporates the four basic components: enabling contexts, resources, tools, and scaffolds as described by Hannafin, et al (1999).

These components are organised around the problem scenario, which is the starting point for the process. The scenario is presented in the form of a video of the mine, with narration based on an interview with the supervising engineer. Interviews with a truck driver and the shovel 
operator are also used, so that the scenario is portrayed as realistically as possible, using vision of the activity and the words used by the people who work there. The video is supported by documentation on the mine, including reports, geological data, mine plan data, mine production data, safety information, machine specifications, and manufacturers' data. Together these materials represent the enabling context of the learning environment. While the information provided is comprehensive, it is not exhaustive and students are still required to research the topic in detail to achieve higher marks. Reference material includes research data, articles and reports on the application of the modelling technique in the mining industry. These form the resource component of the open learning environment. Figure 1 shows the course home page, showing some of the links. Tools to support student learning include online discussions to support interaction within small groups, and discussions for the whole group to promote collaborative learning. Scaffolds include guides to online study and group work.

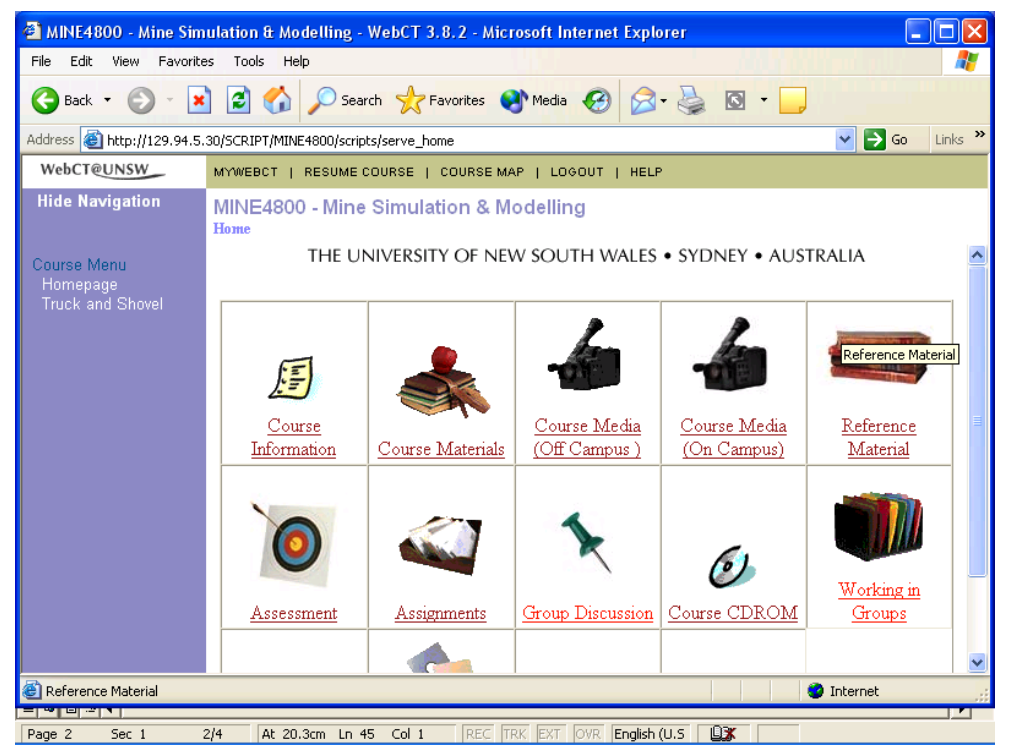

Figure 1: Course material home page (October 2003)

During the course, emphasis was placed on peer interaction during informal tutorials and seminars, and on group work for the 3D VR modelling task. The students were randomly placed in groups of $4-5$, and each group member assigned a role within their respective group. The first activity for the groups was to complete a learning contract. The learning contract is completed by the group members following a discussion on 
how the group will work together to complete the PBL task. This encourages the students to think about the process in advance, and to consider their roles. Each group was provided with an online discussion in WebCT to assist with group processes. This support was optional as students could also meet face to face, and could prefer to meet in that way without supplementing this with the online discussion. Peer interaction was also encouraged with an online discussion focused on a report to the mining industry on the potential and current practice of 3D VR modelling in the industry. The online discussion was used to encourage students to learn collaboratively while considering the implications of this report and to exchange ideas and perspectives so that a deeper understanding of the report may be attained. To ensure intergroup interaction, each group was assigned a piece of equipment that required a complementary piece of equipment to fulfil its role in the simulation. For example in a truck and shovel operation neither truck nor shovel can operate in isolation. Therefore, the 'truck team' must collaborate with the 'shovel team' to achieve a successful outcome and vice versa. Online discussion was an important part of the course design, as a range of discussion points around the research and reference material were aimed at stimulating the students to engage with this.

Mine 4800 used the PBL principles adapted from Dolmans et al (1997) as discussed above. The students are presented with a mine site scenario that reflects the student's experience gained during earlier industry visits and periods of industrial training. The problem based scenario discussed and used in the course is the removal of overburden at a mine site during coal mining operations via a truck and shovel operation. Inefficiencies in the operation can cause significant safety problems and poor financial performance. To address this, students were asked to develop a 3D Virtual reality model that allows the mining process and the impact of several variables to be modelled so that the most efficient and safe method of overburden extraction maybe identified.

The course materials also presented several basic concepts in the development of 3D models and the application of safety information and virtual reality technology. The information under 'course materials' and 'reference materials' on the WebCT site provided a framework of information and scaffolding on which the issues and technical difficulties that may be encountered during development of the simulation could be identified. The use of the online materials in conjunction with tutorials also stimulated students in self directed learning, through the assimilation of knowledge from 'state of the art' publications and revisited experiences presented by earlier virtual reality experimentalists. The ingenuity and amount of information uncovered by the students was high to the point where one student uncovered a series of photographs used at a mine site 
for training mine workers in the exactly the type of operation presented in the scenario.

The VR software tools used to build and execute the VR models were:

- 3DS Max, a widely available software package for building high quality 3D models.

- Polytrans, a 3D file conversion package.

- Safe-VR, a 3D interactive viewer package.

These packages were used due to their availability in the School of Mining Engineering. Except for Safe-VR, these packages are available as educational versions at relatively low cost. A potential off campus offering, however, would have used VRML, Virtools, or AON. These are generally available as free educational downloads. There are many other free downloads for model building and evaluation.

\section{Learning outcomes}

The learning outcomes expected from the course were that undertaking the course would result in students being able to,

- Design and develop an interactive, immersive 3 dimensional model of a mine operation based on real mine data.

- Apply VR technology to the identification and remedy of safety, training or production problems associated with mine planning and operation.

- Justify the cost of 3D modelling and identify when 3D modelling is appropriate as a tool for visualisation and problem solving.

The last of the above learning outcomes expects that students should be able to evaluate when the time spent in developing a VR model was a justified expenditure of time. In a real environment this would be a large cost. In their report, the students were expected to justify their model and comment on where alternatives could be used, still photographs for example or a simple sketch. This point was identified very well in the case of the students report on the positioning of the truck adjacent to the shovel. They found that in some instances, photographs could certainly show the correct positioning of the truck. However, when production data and safety information were to be included, immersive virtual reality models were preferable over still images as they allowed interaction with the 3D model. An example of the truck model developed by the students is shown in Figure 2. The truck and shovel model is excellent example of students utilising the four basic courseware components that enable and support $\mathrm{PBL}$ in an open learning environment. 

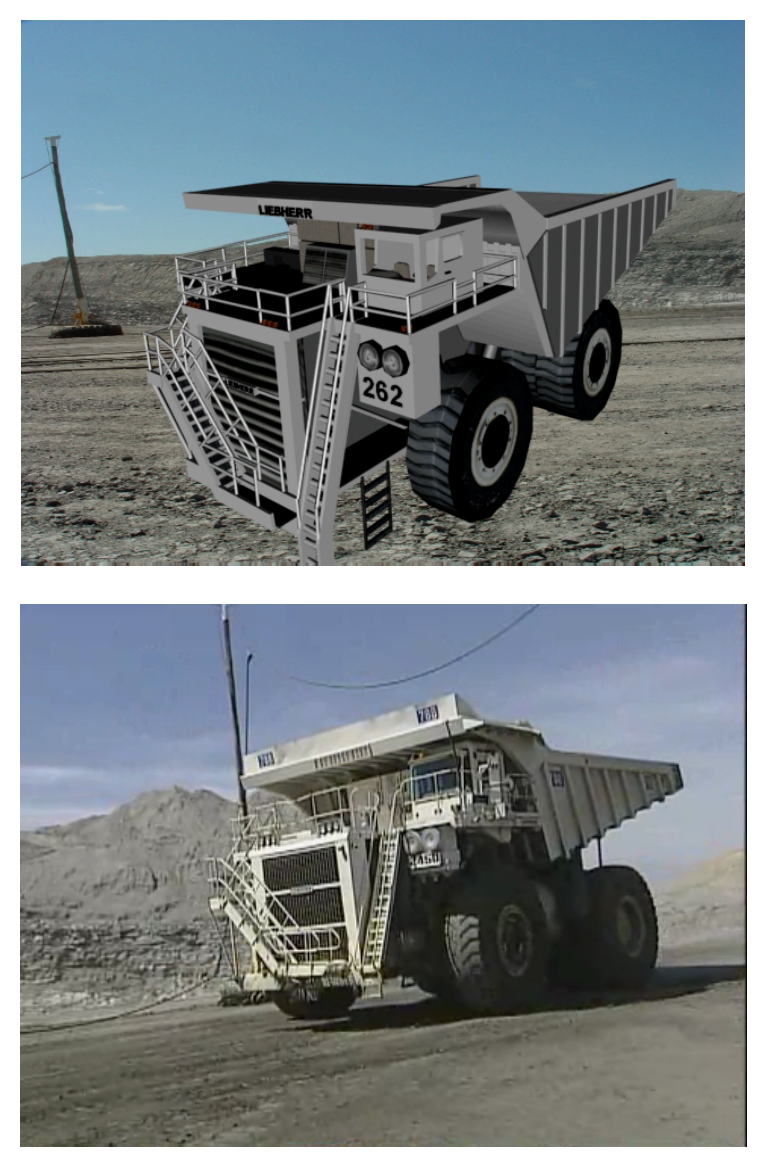

Figure 2: Example VR Model developed by Mine 4800 students (above) and the real thing (below)

The PBL approach was intended to encourage the development of additional capabilities. These include being able to:

- work collaboratively on team projects;

- solve complex problems based on professional practice.

The learning task was designed to develop these capabilities. These were not formally assessed. The course evaluation, however, was designed to elicit feedback from the students on the effectiveness of problem solving while working in teams. 


\section{Student learning approaches}

The Mine 4800 course was under development and as such, two slightly different approaches to the delivery of the course were taken. In 2002, the students were given an introductory lecture and presented with the concept of online course materials, what they had to do and how they should go about it. The problem was deliberately 'ill structured' as described by Jonassen and Reeves (1996) so that the students were forced to make their own decisions and use the materials presented online. The intention was to expose students to self directed learning. One learning activity was to contribute to an online group discussion. The material discussed ranged from the results of a feasibility study into the use of virtual reality for training mine workers in safe operating procedures around a truck and shovel operation, to the assessment of the tools that are available to model and visualise mining operations in real time in three dimensions. The students were also asked to discuss problems that they may have with the modelling process itself. To actively stimulate the students in the discussion, the online discussion was weighted at $20 \%$ of the overall mark. This was a sufficient catalyst for the less focused students.

The 2002 group embraced this technology and presented some good arguments and introduced some new information. An example of a student's online discussion response follows:

Certainly interaction with other virtual mine workers is a great idea in making the VR world and working environment as real as possible. However, we need to balance this against increased complexity of the training system, and the cost and space required for such a system. If training involves a singular task, like truck driving, then group virtual reality isn't really necessary. If a group virtual reality training model is chosen, then the training should include members of their future "crew" ie $\mathrm{u} / \mathrm{g}$ coal development crew. It is important that future crew members gain experience in working with 'their' crew, rather than a whole lot of other 'newbies'. Yes, they can learn from other 'newbies' mistakes, but familiarity of a person's job, crew, and work environment are essential for the crew's safety as a whole. Working in teams involves reliance on other people for your safety. Paul Goodman (this info is not on webct) has written several papers that talk about lack of such familiarity having a negative effect on safety and productivity, although he did not speak about this in regards to VR.

Overall, the students in this group embraced the problem and presented a satisfactory model and report. The only area that students were noticeably reluctant was in the area of the self directed learning required to begin 3D model development. Despite the students being engineering students, they seemed reluctant to experiment with the software and investigate the more advanced modelling techniques that make 3D modelling and animation relatively straight forward. An area in which the students excelled was in 
researching and acquiring new material from mine sites. In at least two of the groups, students visited mines to collect information.

The 2003 group was completely different. These students had the same introductory lecture with the same information and the same $20 \%$ of the overall mark assigned to online discussion of the material. However, the students never really engaged with the online discussion. In response to comments from the previous year, two tutors were made available for two hours per week in the laboratory to help students with technical issues with 3D modelling in an attempt to have the students experiment with the software in more depth. Unfortunately, the students mistook this for a lecture and despite continued information to the contrary, it was not until week six that students actually realised that they had to go online to acquire the relevant information to build their model and had to contact mine sites and equipment manufacturers to collect additional information.

The organisation within the groups was also noticeably different than in the previous year. In 2002, the groups were randomly chosen. In 2003, where possible, the groups were kept the same as for other major projects that year. However, it was noticeable that no particular leaders emerged within the groups even though they were all assigned a particular role. A part of the course that the students did approach very well in this group was the online quiz questions. This is confusing though because the information needed to complete the quiz was online. The quizzes were individual efforts and this may be a factor. An aside that is worthwhile mentioning at this point is that in the past two years, the number of jobs available to students has increased dramatically to the point where each student has the choice of at least two or three jobs in the industry. In the case of the students for the 2003 course, it was highly noticeable across the complete mining engineering program that the competitive edge and student focus had diminished in this group when compared to previous years. Complacency appeared to have taken hold.

Overall, the student learning approaches were different between the two groups and the first group was more engaged than the second. Despite this, both groups completed the course, produced a model, and demonstrated relevant knowledge that could be applied to a real world problem.

\section{Evaluation}

Data gathering for student evaluation has been by an end of course questionnaire. The first offering in 2002 used a standard course evaluation questionnaire. While this indicated overall student satisfaction with the course, it was not designed to provide feedback on specific processes. This 
data was published in an earlier paper (McAlpine \& Stothard, 2003). After the second offering, in 2003, the students were asked to complete an evaluation form designed to elicit information on PBL processes. The evaluation form used in 2003 included questions on the ease of access to the online technology, support and guidance in its use, cognitive development from the learning activities, development of teamwork and problem solving capabilities. All questions on the questionnaire are generic, to elicit responses to the PBL process rather than knowledge of any specific content which is evaluated in other ways through assessment. The form is designed to be used for any PBL course with an online support component.

Table 1 shows the questions on cognitive aspects of the problem scenario. At a cognitive level, the PBL approach is designed to present students with a challenge, to foster the elaboration and enhancement of existing knowledge structures while the students construct new knowledge based on their efforts to meet the challenge. By learning that they can resolve complex problems of a professional nature it is expected that students will learn an approach to problem solving that they may apply in a future professional environment. The questions in Table 1 were included to determine whether the students perceived that they were appropriately challenged, that they built new knowledge on their existing knowledge structures, and that they felt they developed problem solving capabilities.

Table 1: Evaluation feedback on the problem scenario

\begin{tabular}{|c|c|c|c|c|c|c|}
\hline & $\begin{array}{c}\text { SA - Strongly Agree, A - Agree, NS - Not Sure } \\
\text { D - Disagree, SD - Strongly disagree }\end{array}$ & SA & A & NS & D & SD \\
\hline 13 & $\begin{array}{l}\text { The problem/project topic had some features that } \\
\text { were familiar to me. }\end{array}$ & 2 & 5 & & 1 & \\
\hline 14 & $\begin{array}{l}\text { I found the problem / project topic appropriately } \\
\text { challenging. }\end{array}$ & 2 & 5 & & 1 & \\
\hline 15 & $\begin{array}{l}\text { The problem/project enabled me to build on } \\
\text { knowledge I already had }\end{array}$ & 1 & 6 & & 1 & \\
\hline 16 & $\begin{array}{l}\text { I developed new knowledge by working on the } \\
\text { problem/project }\end{array}$ & 2 & 6 & & & \\
\hline 17 & $\begin{array}{l}\text { I learned little that was new by working on the } \\
\text { problem/ project }\end{array}$ & & & & 7 & 1 \\
\hline 18 & $\begin{array}{l}\text { I learned a method of approaching new problems by } \\
\text { carrying out the problem/project tasks. }\end{array}$ & & 6 & 1 & 1 & \\
\hline 30 & $\begin{array}{l}\text { My studies in this subject helped me to develop } \\
\text { problem solving skills that will be useful to me } \\
\text { professionally. }\end{array}$ & 2 & 5 & 1 & & \\
\hline
\end{tabular}

The data from Table 1 suggest that the students' perception was in accord with the intended outcomes from these processes. A later question ( $Q$ 30) indicates that the problem skills would be valuable to them in a 
professional capacity, an important intention of the PBL approach to this course.

As cognitive development and broader capabilities relating to communication and working in teams may be enhanced by group work, it is useful to consider this influence on the learning process. Group work is an important feature of the PBL approach. Working in groups encourages deeper learning by fostering idea sharing and discussion, exposing the student to a range of perspectives and enabling students to learn from each other, Questions 20-26 (Table 2) were included to elicit feedback on how these processes contributed to the students' learning.

Table 2: Evaluation feedback on group work

\begin{tabular}{|c|c|c|c|c|c|c|}
\hline & $\begin{array}{c}\text { SA - Strongly Agree, A - Agree, NS - Not Sure } \\
\text { D - Disagree, SD - Strongly disagree }\end{array}$ & SA & A & NS & D & SD \\
\hline 20 & $\begin{array}{l}\text { The learning contract helped my group to develop a } \\
\text { way of working well together }\end{array}$ & 1 & 3 & 1 & 3 & \\
\hline 21 & $\begin{array}{l}\text { The guidelines for group work were a valuable } \\
\text { support }\end{array}$ & 1 & 3 & 3 & 1 & \\
\hline 22 & $\begin{array}{l}\text { I had to consider several different points of view } \\
\text { from group members during group discussion of the } \\
\text { problem tasks. }\end{array}$ & 1 & 4 & & 2 & \\
\hline 23 & $\begin{array}{l}\text { I worked closely with other students on the group } \\
\text { learning tasks. }\end{array}$ & 2 & 6 & & & \\
\hline 24 & $\begin{array}{l}\text { I learned a lot from the other students in my group } \\
\text { while working on the group learning tasks. }\end{array}$ & 1 & 3 & 2 & 1 & 1 \\
\hline 25 & $\begin{array}{l}\text { Working in a group created a valuable learning } \\
\text { experience. }\end{array}$ & 2 & 3 & & 1 & 1 \\
\hline 26 & $\begin{array}{l}\text { Online discussions were useful for working on group } \\
\text { assignments. }\end{array}$ & 2 & 4 & & 1 & 1 \\
\hline 29 & $\begin{array}{l}\text { I felt that I developed a deep understanding of the } \\
\text { course content. }\end{array}$ & 2 & 2 & 1 & 2 & \\
\hline
\end{tabular}

Table 2 shows a more equivocal response from the students than Table 1. In this table the first two responses (Qs 20 and 21) relate to a leaning contract and guidelines for group work that were made available to the students. The responses relating to these two points are split across the students. Half seem to agree that the learning contract helped, half disagree. Similarly, only half agreed that the guidelines for group work were a valuable support. The resources arranged to support group work had limited success in this instance.

Some reluctance to use the resources on group work does not mean that the group work wasn't successful as a learning experience. The students mostly agreed that they considered several perspectives ( $Q 22)$, they 
worked closely together (Q 23), and that working in groups was a valuable learning experience $(\mathrm{Q} 25)$. There was less agreement about learning a lot from the other students and developing a deep understanding of the course content. These data indicate a qualified success for the outcomes of group processes. The response to the value of online discussions for group work (Q 26) was surprising. The students generally did not engage with the online discussion, yet they did find it useful for working on group assignments. This was demonstrated in the online discussion where students mostly discussed the 'who does what' part of their assignment.

Discussion of the course material or the introduction of new material did not occur as it did in 2002. A couple of comments that may explain this reluctance were included by students in the 'additional comments' section of the questionnaire. The individuals felt that it was "Too small a group, we all know each other" and "Online discussion not really useful for large discussions in this course. Not enough people and we see each other all the time anyway."

\section{Discussion}

The aims for this development were to use student centred active learning approaches to make the learning process as engaging as possible, to encourage higher order learning outcomes, and to enable off campus students to study the course in the same way as on campus students. The problem based design was applied to encourage student engagement by involving them in a learning task that is an authentic application of the VR technology, so that the students could learn how to use it to problem solve in a mining environment. The higher order learning tasks involve analytical processes associated with the mine scenario, and an evaluative process in which the students developed a 3D VR model and justified its use in the context of a working mine. To enable off campus access to the same processes the course was entirely online so that all access and learning activities were facilitated in this way. Some on campus facilitation for software development was provided in the second offering of the course as an extra support. This, however, was not an essential part of the learning process for the students, so that full participation would be possible for off campus students. The course has been offered in this mode twice, providing an opportunity for some evaluative reflection on the course design and student engagement.

The truck and shovel scenario was embraced by the students and presented a problem that was real and directly relevant to the profession of mining engineering. The direct relevance to their chosen profession gave the students a type of ownership of the problem in that they identified with the 
problem and saw the usefulness of the exercise. The students could see that the 3D modelling software was a tool that they may use in the future in a mining operation. In both years that the course was run, the students could identify with the problem immediately. The students were challenged by the problem and in both years the students managed to produce a 3D model successfully. The task appeared to be an effective stimulus and the students responded well to the PBL approach.

While the overall PBL process seemed to be successful, there was some reluctance among students in the 2003 class to engage with online discussion. This was on a part of the course that includes research on the value of 3D VR modelling in the mining industry. The students reported that the group was too small and they all knew each other anyway. This suggests that this group of students saw no purpose in the discussion, even though it was $20 \%$ of their marks. It appears that they did not perceive a clear task to accomplish by online discussion, which Bunker \& Vardi (2001) and Salmon (2002) identify as being important to the success of this mode of learning. Interestingly the 2002 class showed no such reluctance. The reason for the difference between the two classes is not clear. Possible reasons are an awareness among the 2002 class that they were the first to try out a new method, and an apparent lack of motivation among the 2003 class. Evaluation data show that the 2003 class found the online discussion useful for their small group assignments, although this was for organisational rather than conceptual processes.

As online discussion would be an important learning activity for off campus students, including group activities, further development of the course would need to include processes to facilitate online learning activities, such as clarifying tasks to be achieved by online discussion, and additional facilitation techniques such as moderated startup activities. Additional off campus students would create a larger group, which may be an advantage. Unfortunately this option has not been explored as the course is not currently being offered.

\section{Conclusions}

The problem based approach appears to have been successful in stimulating the students to learn the software techniques to create a 3D VR model of a mine component for training or work process analysis and improvement. The approach involved the students working in groups to create the model, and to research and write reports that provided a high level analysis and evaluative framework for the application of the technology. An aim of using a PBL approach is to engage the students in learning activities that require high level processes in a learning 
environment that reflects some of the complexity of a real professional situation, By working through the model building activity and preparing a report on the likely effectiveness and cost effectiveness of the technique, the students engaged with the learning activity in an effective way. Evaluation data suggest that the cognitive processes associated with the PBL approach, including the group work aspect, were effective for these students even though there was some reluctance to use some of the online features, such as online discussions. In a situation in which a very small group are all on campus and working together, this reluctance is understandable.

It seems likely that the course would be effective for both off campus and on campus students, all would be engaged in the same activities, if the course was to be offered in this way. The online activities meant that all necessary learning processes were included in the online environment. Unfortunately, this development can only be fully tested if the course is offered in this mode at a later date. If this were to happen, appropriate facilitation methods with a wider group should create a different perception of the importance of online discussions, and enable the students to study the course effectively in a mixed mode.

\section{References}

ACDE (2001). New learning: A charter for Australian education. Canberra: Australian Council of Deans of Education.

http: / / acde.edu.au/assets / pdf/CharterforAustralianEducation.pdf

Anthonysamy, P. (2005). E-learning design for engineering education. In P. Kommers \& G. Richards (Eds), Proceedings of ED-MEDIA 2005 World Conference on Educational Multimedia, Hypermedia and Telecommunications, 27 June - 2 July, Montreal, Canada.

Biggs, J. (1999a). Teaching for quality learning at university. Society for Research into Higher Education and Open University Press.

Biggs, J. (1999b). What the student does: Teaching for enhanced learning. Higher Education Research and Development, 18(1), 57-75.

Bonk, C. J., Kim, K. \& Zeng, T. (2005). Future directions of blended learning in higher education and workplace learning settings. In P. Kommers \& G. Richards (Eds), Proceedings of ED-MEDIA 2005 World Conference on Educational Multimedia, Hypermedia and Telecommunications, 27 June - 2 July, Montreal, Canada. (pp. 3644-3649).

Bowden, J., Hart, G., King, B., Trigwell, K. \& Watts, O. (2000). Generic capabilities of ATN university graduates. Teaching and Learning Committee, Australian Technology Network. [verified May 2003] http:/ / www.clt.uts.edu.au/ ATN.grad.cap.project.index.html 
Bunker, A. \& Vardi, I. (2001). Why use the online environment with face-to-face students? Insights from early adopters. Proceedings ASCILITE 2001 Conference, Melbourne, Australia. pp 111-116.

http:/ / www.ascilite.org.au/conferences/melbourne01/pdf/papers/bunkera.pdf

Challis, D., Holt, D. \& Rice, M. (2005). Staff perceptions of the role of technology in experiential learning: A case study from an Australian University. Australasian Journal of Educational Technology, 21(1), 19-39.

http: / / www.ascilite.org.au/ajet/ ajet21/ challis.html

Collis, B. \& Moonen, J. (2001). Pedagogy: making the U turn. In Flexible learning in a digital world: experiences and expectations. Chapter 5. Kogan Page.

Dochy, F., Segers, M., Van den Bossche, P. \& Gijbels, D. (2003). Effects of problembased learning: A meta-analysis. Learning and Instruction, 13, 533-568.

Dolmans, D. H. J. M., Snellen-Balendong, H., Wolfhagen, I. H. A. P. \& van der Vleuten, C. P. M. (1997). Seven principles of effective case design for a problembased curriculum. Medical Teacher, 19(3), 185-189.

Hannafin, M. J., Land, S. \& Oliver, K. (1999). Open learning environments: Foundations, methods and models. In C. M. Reigeluth (Ed), Instructional-design theories and models (Vol. 2, pp. 115-140). Mahwah, NJ: Lawrence Erlbaum.

Herrington, J., Oliver, R. \& Reeves, T. C. (2003). Patterns of engagement in authentic online learning environments. Australian Journal of Educational Technology, 19(1), 59-71. http: / / www.ascilite.org.au/ajet/ajet19/herrington.html

IEAust (1999). Manual for the accreditation of professional engineering programs. [viewed Mar 2004]

http: / / www.ieaust.org.au/membership/res/downloads/AccredManual.pdf

Jonassen, D. H. \& Reeves, T. C. (1996). Learning with technology: Using computers as cognitive tools. In D. H. Jonassen (Ed), Handbook of research on educational communications and technology (pp. 693-719). New York: Simon \& Schuster Macmillan.

Jones, S. \& Richardson, J. (2002). Designing an IT-augmented student-centred learning environment. Quality Conversations: Proceedings HERDSA Conference, Perth, WA, 7-10 July.

http:/ / www.ecu.edu.au/conferences/herdsa/main/ papers/ref/pdf/Jones.pdf

Kanet, J. J. (2003). Problem-based learning for production and operations management. Decision Sciences Journal of Innovative Education, 1(1), 99-118.

Kearsley, G. (2000). Online education: Learning and teaching in cyberspace: Wadsworth.

Keppell, M. (2005). Reusable media-rich problem-based learning cases: Creating learning objects for teacher education. In P. Kommers \& G. Richards (Eds), Proceedings of ED-MEDIA 2005 World Conference on Educational Multimedia, Hypermedia and Telecommunications, 27 June - 2 July, Montreal, Canada. (pp. 1865-1873). 
Koschmann, T., Kelson, A. C., Feltovich, P. J. \& Barrows, H. S. (1996). Computersupported problem-based learning: A principled approach to the use of computers in collaborative learning. In T. Koschmann (Ed), CSCL: Theory and practice of an emerging paradigm. Mahwah, NJ: Lawrence Erlbaum.

McAlpine, I. \& Clements, C. (2001). Problem based learning in the design of a multimedia project. Australian Journal of Educational Technology, 17(2), 115-130. http:/ / www.ascilite.org.au/ajet/ajet17 / mcalpine.html

McAlpine, I. \& Stothard, P. (2003). Using multimedia technologies to support PBL for a course in 3D modeling for mining engineers. In D. Lassener. \& C.

McNaught (Eds), Proceedings of ED-MEDIA 2003 World Conference on Educational Multimedia, Hypermedia and Telecommunications, Hawaii, 24-28 June. (pp. 24492455). Norfolk, VA: AACE.

Newman, D. R., Johnson, C., Webb, B. \& Cochrane, C. (1997). Evaluating the quality of learning in computer supported cooperative learning. Journal of the American Society for Information Science, 48(6), 484-495.

Oliver, R. \& Herrington, J. (2001). Teaching and learning online: A beginner's guide to elearning and e-teaching in higher education. Perth, WA: Centre for Research in Information Technology and Communications, Edith Cowan University.

Reeves, T. C. \& Okey, J. R. (1996). Alternative assessment for constructivist learning environments. In B. G. Wilson (Ed), Constructivist learning environments: Case studies in instructional design (pp. 191-202). Englewood Cliffs, NJ: Educational Technology Publications.

Salmon, G. (2002). E-tivities: The key to active learning. London: Kogan Page.

Savin-Baden, M. (2000). Problem-based learning in higher education: Untold stories. Buckingham: The Society for Research into Higher Education and Open University Press.

Tolhurst, D. (2002). Students' epistemological beliefs and the learning of introductory computing concepts. In P. Barker \& S. Rebelsky (Eds), Proceedings of Ed-Media 2002 World Conference on Educational Multimedia, Hypermedia $\mathcal{E}$ Telecommunications, 24-29 June, 2002; Denver, Colorado, USA. (pp. 1961-1966).

Watson, G. (2002). Using technology to promote success in PBL courses. The Technology Source (May/June).

Dr Iain McAlpine, Educational Development and Technology Centre, The University of New South Wales, Sydney NSW 2052.

Email : i.mcalpine@unsw.edu.au Web: http:/ / www.edtec.unsw.edu.au / Dr Phillip Stothard, School of Mining Engineering, The University of New South Wales, Sydney NSW 2052.

Email: pstothard@eng.unsw.edu.au 